ORIGINAL ARTICLE

\title{
Histochemical Analysis of Glycoconjugates in the Skin of a Catfish (Arius Tenuispinis, Day)
}

\author{
A. Al-Banaw ${ }^{1 *}$, R. Kenngott ${ }^{2}$, J. M. Al-Hassan ${ }^{3}$, N. Mehana ${ }^{3}$ and F. Sinowatz ${ }^{2}$ \\ Addresses of authors: ${ }^{1}$ Medical Laboratory Sciences Department, Faculty of Allied Health Sciences, Kuwait University, PO Box 31470 , \\ Sulaibekhat 90805, Kuwait; \\ 2 Lehrstuhl für Tieranatomie II, University of Munich, Veterinärstrasse 13, D-80539 Munich, Germany; \\ 3 Biological Sciences Department, Faculty of Science, Kuwait University, PO Box 5969, 13060 Safat, Kuwait
}

\author{
*Correspondence: \\ Tel./fax: +965 249 83496; e-mail: \\ aalbanaw@gmail.com
}

With 3 figures and 2 tables

Received June 2009; accepted for publication August 2009

doi: 10.1111/j.1439-0264.2009.00977.x

\begin{abstract}
Summary
A histochemical study using conventional carbohydrate histochemistry (periodic-acid staining including diastase controls, alcian blue staining at $\mathrm{pH} 1$ and 2.5) as well as using a battery of 14 fluorescein isothiocyanate (FITC)-labelled lectins to identify glycoconjugates present in 10 different areas of the skin of a catfish (Arius tenuispinis) was carried out. The lectins used were: mannosebinding lectins (Con A, LCA and PSA), galactose-binding lectins (PNA, RCA), $\mathrm{N}$-acetylgalactosamine-binding lectins (DBA, SBA, SJA and GSL I), $\mathrm{N}$-acetylglucosamine-binding lectins (WGA and WGAs), fucose-binding lectins (UEA) and lectins which bind to complex carbohydrate configurations (PHA E, PHA L). Conventional glycoconjugate staining (PAS staining, alcian blue at $\mathrm{pH} 1$ and 2.5) showed that the mucous goblet cells contain a considerable amount of glycoconjugates in all locations of the skin, whereas the other unicellular gland type, the club cells, lacked these glycoconjugates. The glycoproteins found in goblet cells are neutral and therefore stain magenta when subjected to PAS staining. Alcian blue staining indicating acid glycoproteins was distinctly positive at $\mathrm{pH} \mathrm{1,} \mathrm{but} \mathrm{gave} \mathrm{only} \mathrm{a} \mathrm{comparable} \mathrm{staining} \mathrm{at} \mathrm{pH} 2.5$. The mucus of the goblet cells therefore also contains acid glycoproteins rich in sulphate groups. Using FITC-labelled lectins, the carbohydrate composition of the glycoproteins of goblet cells could be more fully characterized. A distinct staining of the mucus of goblet cells was found with the mannose-binding lectins LCA and PSA; the galactosamine-binding lectins DBA, SBA and GLS I; the glucosaminebinding lectin WGA; and PHA E which stains glycoproteins with complex carbohydrate configurations. No reaction occurred with the fucose-binding lectin UEA and the sialic acid-specific lectin SNA. In addition, the galactose-binding lectins PNA and RCA showed only a weak or completely negative staining of the mucus in the goblet cells. The specificity of the lectin staining could be proved by inhibiting binding of the lectins by competitive inhibition with the corresponding sugars. From these data, we can conclude that the mucus produced by the epidermal goblet cells of A. tenuispinis is rich in mannose, $\mathrm{N}$-acetylgalactosamine and $\mathrm{N}$-acetylglucosamine residues.
\end{abstract}

\section{Introduction}

We have demonstrated that there are four types of Ariid catfish in the northern Arabian Gulf (Al-Hassan et al., 1988). The most abundant species is Arius bilineatus, whose secretions have been the subject of our previous studies (Al-Hassan et al., 1987a,b; Al-Lahham et al.,1987). This species has been consistently misidentified by area fish taxonomists as Arius thalassinus (Al-Hassan et al., 1988). Consequently, all of our previous studies have 
utilized the incorrect nomenclature designating $A$. bilineatus as A. thalassinus in the publications that referred to single fish species only. Arius thalassinus is actually quite rare in Kuwaiti waters.

In general, fish skin comprises three layers; the epidermis, dermis and hypodermis, with an aqueous mucous layer covering the epidermal surface. The hypodermis, as the innermost layer, is closest to the striated muscle underneath the skin. The stratum superficiale, the uppermost layer of the epidermis, shows microridges that contain mucus and antibacterial substances secreted to the surface from mucous goblet cells located in the intermediate stratum of the epidermis (Mittal and Whitear, 1979). The dermis is mainly composed of dense connective tissue with a large amount of collagen fibres, and the hypodermis consists of loosely organized collagen fibres and rich supply of vessels.

Besides normal epithelial cells, fish epidermis contains various types of unicellular glands (Mittal et al., 1994). There has been some confusion in the literature about the identity and nomenclature of these secretory cells, but fine structural studies (Whitear, 1981; Whitear and Mittal, 1983) clearly showed that the epidermis of A. bilineatus, Val. contains two different types of glandular cells, namely goblet (mucous) cells and club cells. The number of goblet cells varies in the different areas of the catfish skin. The composition of the mucus, which they produce, may vary depending on their location. The slipperiness of the mucus is considered to be a result of the presence of high molecular weight gel-forming macromolecules and it is assumed that the predominant gel-forming macromolecules in mucus are glycoproteins.

A specific cell population, the club cells, is found in the epidermis of a number of fishes, including the catfish A. bilineatus, Val. (Whitear and Mittal, 1983). The club cell contents are largely proteinaceous, with comparatively little carbohydrate components. Their functions are not well defined, but some protective roles have been suggested (Cameron and Endean, 1973; Al-Hassan et al., 1985). Several studies also provided evidence that preparations from the skin secretions of $A$. bilineatus can stimulate the rate of wound healing in animals and healing of diabetic foot ulcers in humans (Al-Hassan et al., 1983,1985,1987a,b, 1991; Al-Hassan, 1990).
Our previous efforts concentrated on A. bilineatus because of the healing and biochemical interests associated with its skin secretion. The physical and chemical properties of its skin secretions as well as their effects on superficial wounds in humans are different from those of the skin secretions of $A$. tenuispinis. Whereas A. bilineatus is a migrant to the Kuwaiti territorial waters during the summer months, A. tenuispinis is a resident of the northern shallow mud flats of the coastal waters of Kuwait. In this study, we concentrate on the identification of the carbohydrate components of the lectins produced by the epidermal cells of $A$. tenuispinis.

Our current knowledge on the histochemical analysis of glycoconjugates in the secretory cells of the epidermis in catfish skin is very limited. In most catfish species investigated so far, the contents of the mucus have not been characterized using advanced histochemical methods. In this study, we intend to identify the carbohydrate components of the glycoproteins of the highly biologically active proteinaceous skin secretion of the catfish and in the unicellular glands that produce it. Analysis of glycoconjugates from 10 different areas of the catfish skin has been performed, using conventional methods based on periodic acid-Schiff (PAS) and alcian blue procedures as well as lectin histochemistry.

\section{Materials and Methods}

A total of 20 adult catfish (A. tenuispinis, Day) were caught with baited hook and line in the coastal waters of Kuwait. Their body lengths ranged from 25 to $32 \mathrm{~cm}$ and they weighed 300-450 g. Small tissue samples were obtained from 10 different areas of the skin (Fig. 1) and immediately fixed in Bouin's solution (picric acid $1500 \mathrm{ml}$, glacial acetic acid $500 \mathrm{ml}, 37 \%$ formalin $100 \mathrm{ml}$ ) for $24 \mathrm{~h}$. After fixation, the tissue samples were immersed in $70 \%$ ethanol $(3 \times 24 \mathrm{~h})$ to wash out Bouin's solution. The specimens were then dehydrated in a series of graded ethanol and embedded in paraplast using an automatic tissue processor (Shandon Duplex Processor; Shandon, Frankfurt, Germany) and a Histostat Tissue Embedding Center (Reichert-Jung, Wien, Austria). Sections (5 $\mu \mathrm{m}$ thick) were cut on a Leica rotatory microtome type 1516 (Leica Ltd, Wetzlar, Germany) and collected on polylysine
Fig. 1. Schematic representation of Arius tenuispinis showing the areas of sample collection.

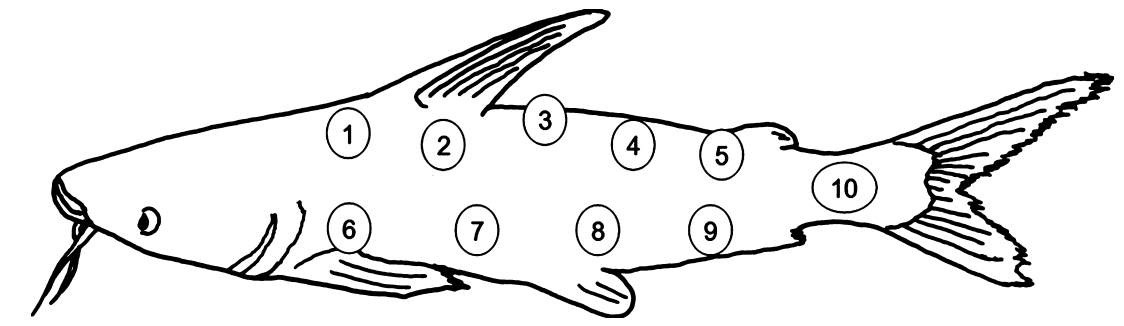


Table 1. Survey of lectins used in this study

\begin{tabular}{|c|c|c|c|c|c|}
\hline Lectin group & Lectin & Origin & Abbreviation & $\begin{array}{l}\text { Major sugar } \\
\text { specification }\end{array}$ & Binding inhibitor \\
\hline \multirow[t]{3}{*}{ Mannose-binding lectins } & $\begin{array}{l}\text { Concanavalin ensiformis } \\
\text { agglutinin }\end{array}$ & Jack bean & Con A & $\alpha-D-M a n>a-D-G l c$ & D-Mannose \\
\hline & Lens culinaris agglutinin & Lentil & LCA & $\alpha$-D-Man & D-Mannose \\
\hline & Pisum sativum agglutinin & Garden pea & PNA & $\beta$-D-Man & D-Mannose \\
\hline \multirow{2}{*}{$\begin{array}{l}\text { Galactose-binding } \\
\text { lectins }\end{array}$} & Arachis hypogea agglutinin & Peanut & PNA & $\beta$-D-Gal(1-3)-D-GalNAC & D-Galactose \\
\hline & Ricinus communis agglutinin & Castor bean & RCA & $\beta$-D-Galactose & $\beta$-D-Galactose \\
\hline \multirow[t]{4}{*}{$\begin{array}{l}N \text {-Acetylgalactosamine- } \\
\text { binding lectins }\end{array}$} & Dolichos biflorus agglutinin & Horse gram & DBA & $\begin{array}{l}\alpha \text {-D-GalNAc } \\
(1-3) \text { GalNAc }\end{array}$ & $\mathrm{N}$-acetyl-D-galactosamine \\
\hline & Glycine max agglutinin & Soja bean & SBA & $\alpha$-D-GalNAC, $\alpha$-D-Gal & $N$-acetyl-D-galactosamine \\
\hline & Saphora japonica agglutinin & $\begin{array}{l}\text { Japanese } \\
\text { pagoda tree }\end{array}$ & SJA & $\alpha$-D-GalNAC & $\mathrm{N}$-acetyl-D-galactosamine \\
\hline & $\begin{array}{l}\text { Griffonia simplicifolia } \\
\text { agglutinin I }\end{array}$ & Griffonia seed & GSL I & $\alpha$-D-GalNAC & $N$-acetyl-D-galactosamine \\
\hline $\begin{array}{l}\text { N-Acetylglucoamine-binding } \\
\text { lectins }\end{array}$ & Triticum vulgare agglutinin & Wheat germ & WGA & $(\mathrm{dGlcNAc}) 2 \mathrm{Neu}-\mathrm{NAc}$ & $N$-acetyl-D-glucosamine \\
\hline Fucose-binding lectins & Ulex europeus agglutinin & Gorse seed & UEA & Fucose & Fucose \\
\hline $\begin{array}{l}\text { Lectins with complex } \\
\text { carbohydrate configurations }\end{array}$ & Phaseolus vulgaris agglutinin & Garden bean & PHA E PHA L & - & - \\
\hline Sialic acid-binding lectin & Sambucus nigra & Elderberry bark & SNA & - & - \\
\hline
\end{tabular}

coated slides (Menzel-Gläser, Braunschweig, Germany). Dewaxed serial sections were stained with Delafields's haematoxylin, eosin and Masson-Goldner.

Conventional histochemical glycoconjugate staining was performed using PAS (including diastase controls) (Pearse, 1985) and alcian blue staining at $\mathrm{pH} 1$ and 2.5 for glycoconjugate expression (Pearse, 1985) in the skin of the catfish. The lectins used in this study are listed in Table 1 and belong to the following six groups of lectins: mannose-, galactose-, $\mathrm{N}$-acetylgalactosamine-, $\mathrm{N}$-acetylglucosamine and L-fucose-binding lectins, and lectins that bind to complex carbohydrate residues. The complete complement of lectins investigated and the oligosaccharide specificity associated with these probes are detailed in Table 1.

Sections ( $5 \mu \mathrm{m}$ thick) of the catfish (A. tenuispinis) skin from 10 different areas (Fig. 1) were dewaxed with xylene $(2 \times 30 \mathrm{~min})$, then rehydrated and thoroughly washed in TRIS buffer $(3 \times 5 \mathrm{~min} ; \mathrm{pH} 6.8)$. Incubation with the respective fluorescein isothiocyanate (FITC)-conjugated lectins $(12 \mu \mathrm{g} / \mathrm{ml}$ TRIS buffer) was performed in a darkened humidified chamber for $1 \mathrm{~h}$. The panel of 14 FITClabelled lectins was used and their respective inhibitors (Schick et al., 2009) are shown in Table 1. After incubation, the sections were gently washed in TRIS buffer $(3 \times 5 \mathrm{~min} ; \mathrm{pH} 6.8)$ and mounted in a mixture of polyvinyl alcohol and ethylene glycol (Serva, Heidelberg, Germany) to probe the slides, and viewed with a Leitz fluorescent microscope. Microphotographs were taken using a confocal laser scanning microscope (LSM
510 Meta; Zeiss, Göttingen, Germany) equipped with a 10× Plan-Neofluar objective (numerical aperture 0.3)/a 20× Plan-Neofluar objective (numerical aperture 0.5)/ a $40 \times$ Plan-Neofluar oil immersion objective (numerical aperture 1.3). The excitation wavelengths used were: $364 \mathrm{~nm}$ for DAPI and 488 for FITC. The resulting fluorescence emissions were detected through emission bandpass filters at $385-470 \mathrm{~nm}$ (DAPI) and 505-530 nm (FITC).

\section{Results}

Depending on the special location, the epidermis of the catfish (A. tenuispinis) consists of three to six layers of epidermal cells, and is mucogenic in nature. The histochemical characteristics of the epidermis and its associated intra-epidermal glands (club glands and mucous goblet cells) did not show significant differences in the 10 areas of the skin studied in this investigation, but their number varied in the different regions. The mucous unicellular glands are usually located in the superficial layers of the epidermis and release their secretion to the surface, where a more or less continuous layer of mucus is formed. The club cells are also unicellular and usually possess a central ovoid nucleus, which is surrounded by a comparatively large amount of homogenous eosinophilic cytoplasm (Fig. 2a,b). Larger club cells are mostly located in the middle layer of the epidermis. Distinct staining of the mucus was not observed after H\&E (Fig. 2a,b) or after Goldner staining (Fig. 2c,d). 
Fig. 2. Histology of the epidermis of the skin of Arius tenuispinis. Scale bar $=25 \mu \mathrm{m}$. (a) Epidermis, area 1, H\&E-staining; 1 club cell; 2 mucous cell; 3 basal membrane. (b) Epidermis, area 6: H\&E-staining; 1 club cell; 2 basal layer of the epidermis; 3 basal membrane. (c) Epidermis, area 1, Goldner staining; 1 club cell; 2 mucous cell; 3 basal membrane; 4 subepidermal connective tissue with numerous melanocytes. (d) Epidermis, area 1, Goldner staining; 1 club cell; 2 mucous cell; 3 basal layer of epidermis; 4 basal membrane. (e) Epidermis, area 1, alcian blue staining, pH 1.0. 1 club cell; 2 mucous cell; 3 melanocyte. ( $f$ ) Epidermis, area 1, alcian blue staining, pH 1.0. 1 Club cell; 2 mucous cell; 3 melanocyte.
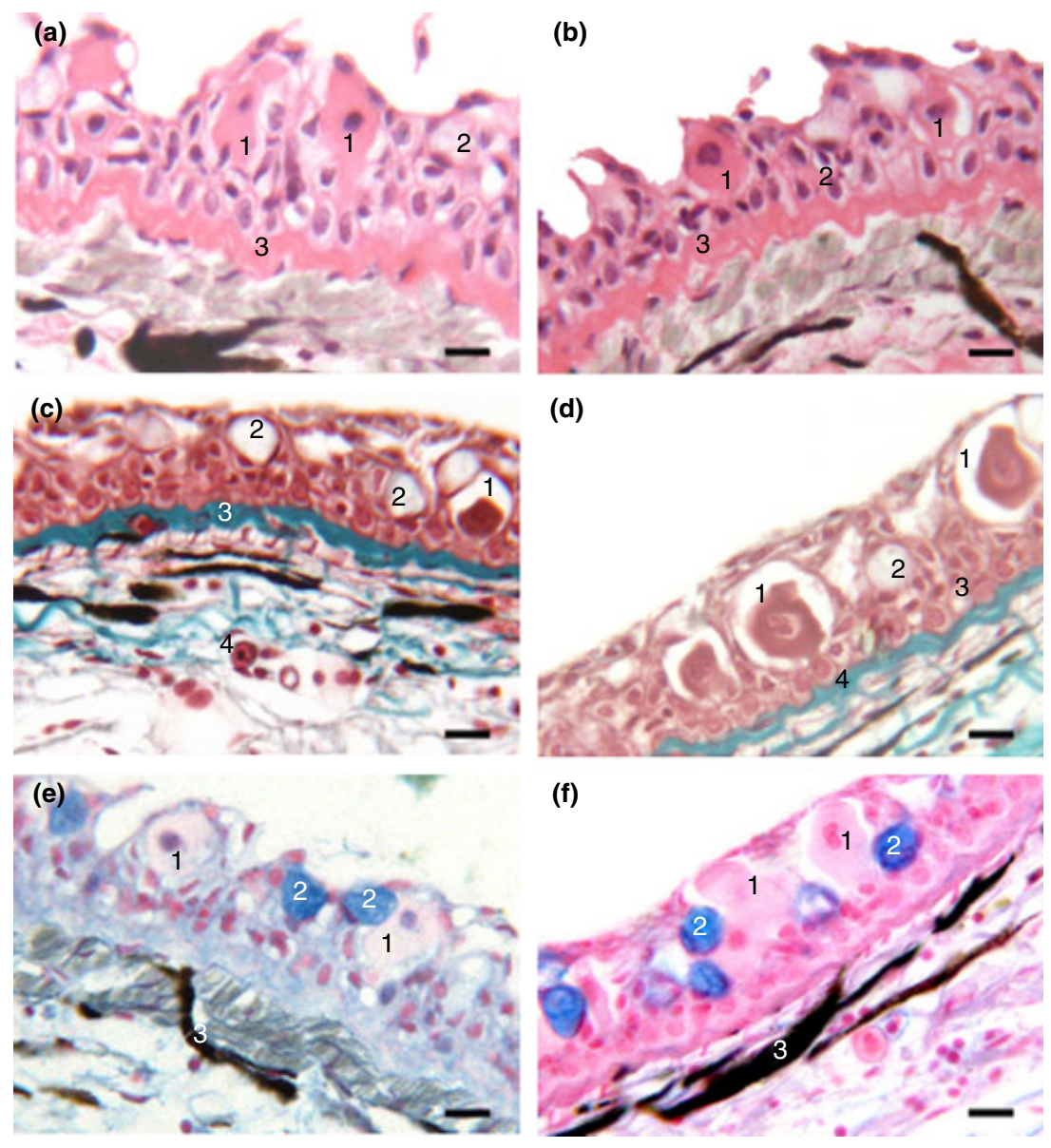

Using conventional glycoconjugate staining techniques (PAS staining, alcian blue at $\mathrm{pH} 1$ and 2.5), it could be confirmed that the mucous cells contain a considerable amount of glycoconjugates in all locations of the skin, whereas the club cells lacked the glycoconjugates. The glycoproteins found in goblet cells stain distinctly magenta when subjected to PAS staining and strongly blue when subjected to alcian blue staining at $\mathrm{pH} 1$ (Fig. 2e,f). Alcian blue at pH 2.5 resulted in a comparatively weak staining of the goblet cells. From these data, we can conclude that the mucus of the goblet cells is rich in neutral and acidic glycoproteins. The acid glycoproteins are obviously quite heavily sulphated, but contain only small amounts of carboxyl groups.

The lectin histochemical staining properties (Fig. 3ah) of the epidermis and subepidermal structures are summarized in Table 2. The contents of the mucous cells mostly appear loosely packed, with a mass of bubble-like vesicles. With lectins, which stain the mucous cells strongly (DBA, SBA, GLS-1), usually a distinctly stronger reaction intensity is found at their periphery. Co-incubation of the FITC-labelled lectins with the corresponding inhibiting sugars (see Table 1) significantly or completely reduced binding to the sections.

\section{Mannose-binding lectins (ConA, LCA and PSA)}

Mannose-binding lectins showed a characteristic staining pattern in all 10 skin areas studied. Whereas LCA (Fig. 3 b) and PSA (Fig. 3c) staining appeared nearly identical (strong staining of mucous cells, weak staining in the epidermis, no staining of club cells), ConA-FITC (Fig. 3a) only weakly stained the mucus and the mucous cells.

\section{Galactose-binding lectins (PNA and RCA)}

Incubation with the galactose-binding lectins PNA and RCA (Fig. 3e) generally resulted only in faint and mostly discontinuous staining of the apical epithelial cells.

$N$-Acetylgalactosamine-binding lectins (DBA, GSL I, SJA and SBA)

These lectins which all have a nominal specificity for $\alpha$-D$\mathrm{N}$-acetylgalactosamine showed divergent staining pattern 

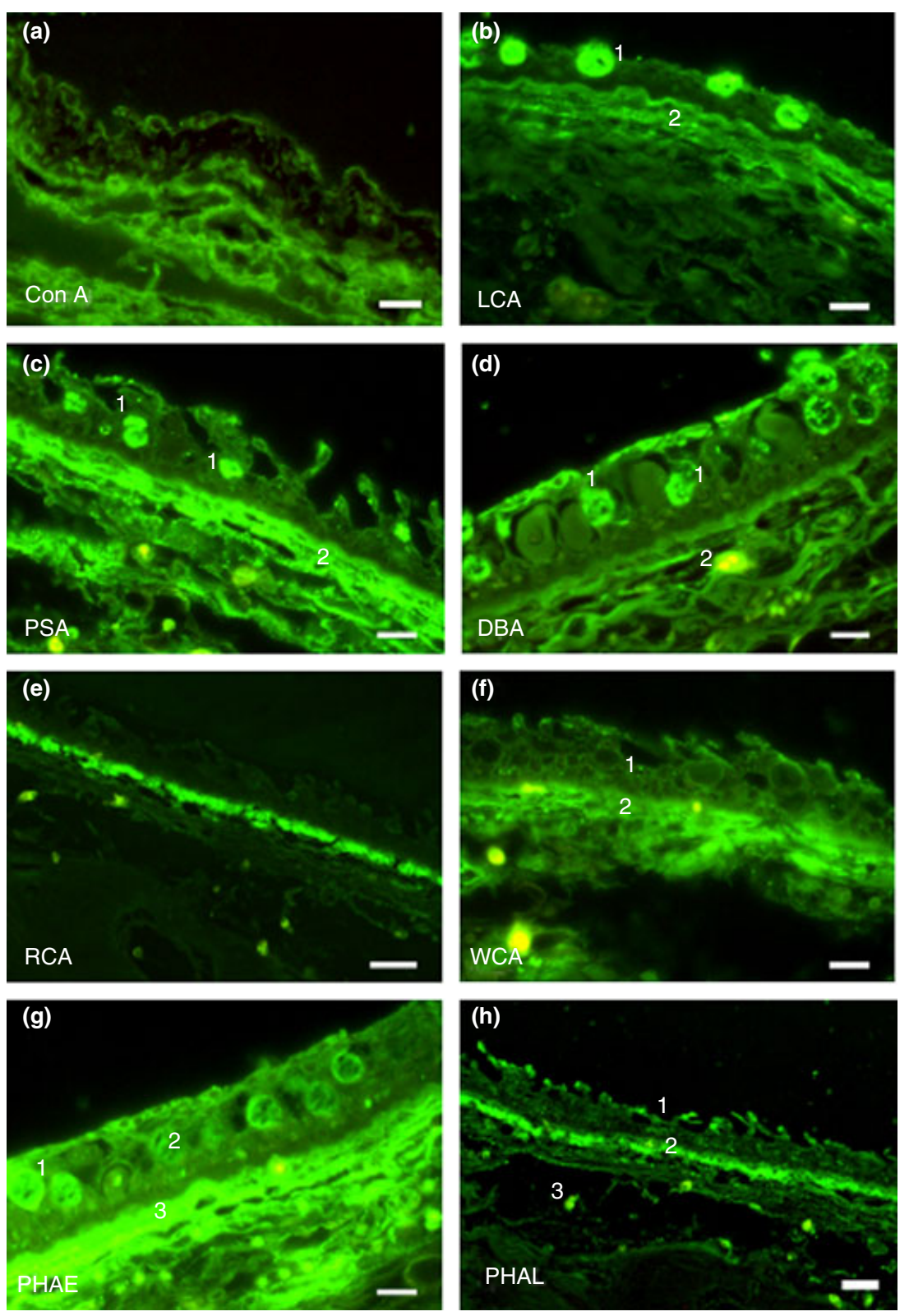

Fig. 3. Lectin-binding sites in the epidermis of the catfish Arius tenuispinis (area 1). (a) A weak binding of ConA-FITC is found in the mucus and the mucous cells. Scale bar $=25$ $\mu \mathrm{m}$. (b, c) Both FITC-conjugated lectins (LCA and PSA) strongly stain the mucous cells. Scale bar $=25 \mu \mathrm{m}$. (d) DBA-FITC strongly stains the mucous cells (1) and the mucus. Distinct staining is also found in the subepidermal connective tissue (2). Scale bar $=100 \mu \mathrm{m}$. (e) RCA-FITC incubation results in a faint and discontinuous staining of the apical epidermal cells. A distinct staining was observed in the dense collagen layer beneath the basal membrane. Scale bar $=25 \mu \mathrm{m}$. (f)WGA-FITC shows a moderate staining of the epidermis (1), whereas the subepidermal connective tissue (2) shows a distinct to strong binding of the lectin. Scale bar $=25 \mu \mathrm{m}$. (g) PHA E-FITC strongly stains the mucus (1) on the surface of the epithelium and the mucous cells. In addition, the subepidermal connective tissue is distinctly stained. Scale bar = $25 \mu \mathrm{m}$. (h) PHA L-FITC stains the mucus on the epidermis surface (1). A distinct binding of this lectin is seen in the subepidermal collagen layer (2). Scale bar $=100 \mu \mathrm{m}$. in the epidermis. Whereas DBA (Fig. 3d), SBA and GSL I distinctly stained the mucous cells of the epidermis, only a weak binding of SJA to the mucus of the goblet cells was found. The strong staining of DBA, SBA and GSL I was usually confined to the peripheral part of the goblet cells, whereas in the central part, a weaker binding of the three FITC-labelled lectins occurred. DBA and SBA also distinctly stained the apical epithelial cells, whereas the deeper cell layers showed only little binding of these two lectins.

\section{$N$-Acetylglucosamine-binding lectin (WGA)}

The periphery of apical cells showed a punctuate fluorescence after incubation with WGA-FITC (Fig. 3f). The mucus of the goblet cells and the mucus on the epidermal surface as well as the basal membrane were distinctly stained, whereas no effect on the club cells was noted.

\section{Fucose-binding lectin (UEA)}

Fucose-FITC did not bind significantly to any structure of the epidermis.

Lectins binding to complex carbohydrate configurations (PHA E and PHA L)

PHA E (Fig. 3g) strongly stained the mucus of the goblet cells and of the epidermal surface, whereas binding 
Table 2. Lectin staining of the epidermis of the catfish Arius tenuispinis

\begin{tabular}{|c|c|c|c|c|c|c|}
\hline Lectin & Apical epithelial cells & Epithelial cells in deeper layers & Mucous on epithelial surface & Goblet cells & Club cells & Basal membrane \\
\hline Con A & + & - & + & - & - & + \\
\hline LCA & + & - & +-++ & +++ & - & +-++ \\
\hline PSA & + & - & +-++ & +++ & - & +-++ \\
\hline PNA & $+($ discont $)$ & - & - & - & - & - \\
\hline $\mathrm{RCA}$ & +- & +- & - & +- & - & - \\
\hline DBA & ++ & & & +++ & - & \\
\hline SBA & +-++ & +- & ++ & ++-+++ & - & ++ \\
\hline SJA & & + & & - & - & \\
\hline GSL I & + & + & +++ & ++ & - & - \\
\hline WGA & + punc, membrane & + punc, membrane & + & ++ & - & +-++ \\
\hline UEA & - & - & - & - & - & - \\
\hline PHA E & ++ & + & ++ & ++-+++ & - & - \\
\hline PHA L & + & + & +-++ & +-++ & - & + \\
\hline
\end{tabular}

- , negative; + , weakly positive; ++ , distinctly positive; +++ , strongly positive staining.

of PHA L (Fig. 3h) appeared somewhat less in both locations.

\section{Sialic acid-binding lectin (SNA)}

This lectin has an affinity for $\alpha$-NeuNAc-[2 $\rightarrow$ 6]-Gal, $\alpha$ NeuNAc-[2 $\rightarrow 6]$-GalNAc, and to a lesser extent for $\alpha$ NeuNAc-[2 $\rightarrow 3]$-Gal residues. Some staining was seen in the apical and basal layers of the epidermis. The unicellular glands, goblet cells as well as club cells were always negative.

\section{Discussion}

The skin of fish is continuously exposed to sea water and because of its direct contact with the environment, its structure and function have been investigated in several studies (Whitear, 1981; Burkhardt-Holm, 1997; Pinky et al., 2008). The mucus on the surface of the skin protects the animal and is an important factor in disease resistance (Shephard, 1994; Pinky et al., 2008). Mucous cells and the composition of the mucus they produce are influenced by endogenous factors (sex, developmental stage) and exogenous factors, such as stress, acid and infections (Blackstock and Pickering, 1982; Zaccone et al., 1985). After exposure to an acidic environment, modifications in the carbohydrate contents are more obvious when defined by lectin histochemistry than those detected by classical histochemical techniques. Low levels of agglutination activities have been observed in skin mucous secretions of several fishes, including gar (Lepisosteus platyhineus), snapper (Lutjaneus griseus) and bowfin (Amia calva) (Fletcher and Grant, 1968; Bradshow et al., 1971). It was speculated that some or all of these activities in mucus could be related to immunoglobulins, as immunoglobulins have been found in the mucus of the Atlantic salmon following immunization with erythrocytes (Harris and Hunt, 1973). Preparations from mucus from many animal sources have been shown to contain immunoglobulins (Pigman, 1977).

Mucins, the main constituents of mucus, are high molecular weight glycoproteins. Some $50 \%$ of their dry weight can consist of carbohydrate chains (BurkhardtHolm, 1997). Although there is extensive information in the literature on this subject (Mittal et al., 1994; Kumari et al., 2009), the carbohydrate nature of the glycoproteins in the unicellular glands in fish epidermis has not been fully characterized.

The Arabian Gulf catfish A. bilineatus, Val. and A. tenuispinis secrete a viscous layer of proteinaceous gel when frightened or injured. The gel-like material adheres to the skin of the fish even when the fish swims at varying speeds and for a number of days. We observed that the gel on the catfish A. bilineatus, Val. peels off in an irregular manner after 3 days or more. Usually, a catfish caught $48 \mathrm{~h}$ after scraping the opaque proteinaceous gel did not elaborate more of the gel, but secreted a transparent, viscous, water-soluble solution, which is reminiscent of mucus. The epidermal secretion of $A$. tenuispinis is more viscous and glue-like compared with that of $A$. bilineatus. The biochemical and pharmacological properties of $A$. tenuispinis skin secretions appear to be similar to those of the secretions of A. bilineatus. Preparations from A. tenuispinis secretions induce lethal response in rabbits comparable with $A$. bilineatus secretions. However, its plasma enzyme activity is lower than that of A. bilineatus (Ali et al., 1989). In this study, a detailed histochemical analysis of the carbohydrate residues found in the epidermis of the catfish A. tenuispinis has been performed. 
Glycoconjugates can be characterized using different histochemical techniques, including lectin histochemistry. In this study, we used conventional histochemical staining methods (PAS reaction, diastase-PAS, alcian blue at $\mathrm{pH} 1$, and 2.5) to distinguish neutral and acidic (carboxylated and sulphated) glycoconjugates, and 14 fluorescein isothiocyanate-labelled lectins with different carbohydrate specificities to identify the presence and distribution of defined sugar residues in the oligosaccharide chains of glycoconjugates.

Using conventional glycoconjugate staining techniques (PAS staining, alcian blue at $\mathrm{pH} 1$ and 2.5) showed that the mucous cells contain a considerable amount of glycoconjugates in all locations of the skin, whereas the other unicellular gland type, the club cells, was consistently lacking these glycoconjugates. The glycoproteins found in mucous cells stain magenta when subjected to PAS staining and therefore contain neutral glycoproteins. Alcian blue staining indicating acid glycoproteins was distinctly positive at $\mathrm{pH} 1$, but gave only a comparable weak staining at $\mathrm{pH}$ 2.5. Therefore, the mucus of the goblet cells also contains acid glycoproteins rich in sulphate groups.

Using 14 different lectins, the carbohydrate compositions of the glycoproteins of mucous cells could be more fully characterized. A distinct staining of the mucus of goblet cells was found with the mannose-binding lectins LCA and PSA; the galactosamine-binding lectins DBA, SBA and GLS I; the glucosamine-binding lectin WGA; and PHA E which stains glycoproteins with complex carbohydrate configurations, whereas no reaction occurred with the fucose-binding lectin UEA and the sialic acidspecific lectin SNA. In addition, the galactose-binding lectins PNA and RCA showed only a weak or completely negative staining of the mucus in the goblet cells. The specificity of the lectin staining could be proved by inhibiting the binding of the lectins using the corresponding sugars. From these data, we can conclude that the mucus produced by the epidermal mucous cells of $A$. tenuispinis is rich in mannose, $\mathrm{N}$-acetylgalactosamine and $\mathrm{N}$-acetylglucosamine residues.

On the contrary, the second type of unicellular glands in the skin of A. tenuispinis, the club cells, stained neither with conventional glycoprotein stains such as PAS and alcian blue, nor with any of the carbohydrate-specific lectins used in this study. Therefore, we can safely assume that their secretions contain no or only little carbohydrate material. These findings confirm earlier observations of Al-Hassan et al. (1982), who clearly showed by using biochemical techniques that the Arabian Gulf catfish secretes copious amounts of viscous proteinaceous gel from epidermal cells when threatened or injured. The term mucus applies to substances in which carbohydrates constitute a predominant percentage (mostly $60 \%$ or more).
The epidermal gel secretion of $A$. bilineatus is unlike what can be generally termed mucus. Over $85 \%$ of the dry weight of the gel secretion is protein, with lipids $(13.4 \%$ of the dry weight) and only small amounts of carbohydrates and nucleic acids. The lipid fraction contains a relatively high level of arachidonic acid, a mixture of eicosanoids, cholesterol and cholesteryl esters, as well as polar lipids (Al-Hassan et al., 1986a). The proteins are composed of two major fractions, the water-insoluble $\alpha$-helical structures and the phosphate buffer-soluble fraction (Al-Hassan et al., 1987b). The soluble fraction contains amongst other biologically active proteins and peptides a mixture of enzymes whose properties resemble those of some components of animal venom. However, other proteins that have been studied include a lectin-like haemagglutination factor (Al-Hassan et al., 1982, 1986c), a haemolytic factor (Al-Hassan et al., 1982; Al-Lahham et al., 1987) and vasoactive components (Al-Hassan et al., 1986b; Al-Bow et al., 1997). The catfish gel haemagglutination factor (CHF) has a specific activity expressed as titre per mg protein, is extremely high, $>10 \times 10^{6}$, making it one of the most active soluble animal lectins isolated to date. Our previous studies showed that $\mathrm{CHF}$ recognizes red blood types (Al-Hassan et al., 1986c). Human blood types A and B had similarly high titre levels of CHF in all cases tested, but type $\mathrm{O}$ was variable. One-half of the type $\mathrm{O}$ donors tested gave a positive agglutination response, whereas the other half was negative (20 subjects in total), indicating that additional determinants may be involved. Sheep red blood cells also showed variability similar to that noted for human type O cells. Several studies have convincingly established that the repeated application of preparations involving catfish epidermal secretions to wounds and persistent diabetic foot ulcers in human subjects had a positive effect on wound healing (Al-Hassan, 1990; Al-Hassan et al., 1991). The complex mixture of components contained in the epidermal secretion obviously induces a balanced stimulation of the early stages of wound healing. Despite intensive research, the exact nature and role of the wound healing components secreted by club cells are not known, although synergistic effects by the different biologically active components are expected. Our observations during treatment of diabetic and gangrenous foot ulcers using preparations from the skin of the Arabian Gulf catfish A. bilineatus showed that healing progressed smoothly in most cases without the use of antibiotics, although the lesions were highly infested with a variety of micro-organisms. The appearance of large numbers of macrophages during the early stages of treatment of incised wounds in test animals only points to the enhancement of the immune system of the treated animals by the catfish preparations (Al-Hassan et al., 1991). Recent studies of the Japanese conger eel 
Conger myriaster have shown that their club cells secrete a specific galectin called congerin into the epidermal mucus (Nakamura et al., 2001). The authors hypothesize that congerin participates in innate immunity on the intra- and the extra-body surface of the conger. In future studies, we intend to establish whether galectins or galectin-like proteins are components of the proteinaceous secretions of the club cells in the epidermis of the catfish A. tenuispinis, and the other three Ariid catfish species found in the Arabian Gulf, namely A. bilineatus, A. thalassinus and Arius dussumieri, and whether they play a role in the positive wound healing effects of the epidermal secretions in these species.

\section{Acknowledgements}

The authors acknowledge with gratitude the support rendered for our project by His Highness Sheikh Jaber Al-Ahmad Al-Sabah 'The Late Amir of Kuwait'. We also thank His Excellency Sheikh Nasser Mohammad Al-Ahmad Al-Sabah 'The Prime Minister of Kuwait' for his help and support. We also thank Mr Mohammad Al-Naki for his generous support. This project was partly supported by Kuwait Foundation for the Advancement of Science grant No.80-40-02 and Kuwait University grant No. SBO17.

\section{References}

Al-Bow, H. A., J. M. Al-Hassan, M. Thomson, O. Thulesius, and A. Elkhawad, 1997: Multiple vasoactive factors in epidermal secretions of the Arabian Gulf Catfish Arius bilineatus (Valenciennes). Gen. Pharmacol. 28, 737-744.

Al-Hassan, J. M., 1990: Diabetic ulcer healing preparations from the skin of the Arabian Gulf catfish (Arius bilineatus val.): a novel and effective treatment. Int. J. Tiss. React. 12, 121-135.

Al-Hassan, J. M., M. Thomson, and R. S. Criddle, 1982: Composition of the proteinaceous gel secretion from the skin of the Arabian Gulf catfish (Arius thalassinus). Mar. Biol. 70, 27-33.

Al-Hassan, J. M., M. Thomson, and R. S. Criddle, 1983: Accelerated wound healing preparation from the skin of the Arabian Gulf catfish. Lancet 1, 1043-1044.

Al-Hassan, L. M., M. Thomson, K. R. Criddle, B. Summers, and R. S. Criddle, 1985: Catfish epidermal secretions in response to threat or injury: a novel defense response. Mar. Biol. 88, 117-123.

Al-Hassan, J. M., M. Afzal, M. Ali, M. Thomson, T. Fatima, S. Fayad, and R. S. Criddle, 1986a: Lipid composition of the epidermal gel secretion from the Arabian Gulf catfish, (Arius thalassinus, Ruppell). Comp. Biochem. Physiol. 85B, 41-47.

Al-Hassan, J. M., M. Thomson, M. Ali, S. Fayad, A. Elkhawad, O. Thulesius, and R. S. Criddle, 1986b: Vasoconstrictor components of the Arabian Gulf catfish, (Arius thalassinus, Ruppell) proteinaceous skin secretion. Toxicon 24, 10091014.

Al-Hassan, J., M. Thomson, B. Summers, and R. S. Criddle, 1986c: Purification and properties of hemagglutination factor from Arabian Gulf catfish (Arius thalassinus, Ruppell) epidermal secretion. Comp. Biochem. Physiol. 85B, 31-37.

Al-Hassan, J. M., M. Thomson, M. Ali, and R. S. Criddle, 1987a: Toxic and pharmacologically active secretions from the Arabian Gulf catfish (Arius thalassinus, Ruppell). Toxin. Rev. 6, 1-43.

Al-Hassan, J. M., M. Thomson, B. Summers, and R. S. Criddle, 1987b: Protein composition of the threat induced epidermal secretion from the Arabian Gulf catfish Arius thalassinus (Ruppell). Comp. Biochem. Physiol., B. 88, 813-822.

Al-Hassan, J. M., D. A. Clayton, M. Thomson, and R. S. Criddle, 1988: Taxonomy and distribution of Ariid catfishes from the Arabian Gulf. J. Nat. Hist. 22, 473-487.

Al-Hassan, J. M., M. Dyson, S. R. Young, M. Thomson, and R. S. Criddle, 1991: Acceleration of wound healing induced by preparations from epidermal secretions of the Arabian Gulf catfish (Arius bilineatus, Valenciennes). J. Wilderness Med. 2, 153-163.

Ali, M., M. Thomson, J. M. Al-Hassan, J. Al-Saleh, S. Fayad, H. Assad, and R. S. Criddle, 1989: Comparative biochemical and pharmacological properties of epidermal secretions from Ariid catfish of the Arabian Gulf. Comp. Biochem. Physiol. 92, 205-211.

Al-Lahham, A., J. M. Al-Hassan, M. Thomson, and R. S. Criddle, 1987: A hemolytic protein secreted from epidermal cells of the Arabian Gulf catfish, Arius Thalassinus (Ruppell). Comp. Biochem. Physiol., 87B, 321-327.

Blackstock, N., and A. D. Pickering, 1982: Changes in the concentration and histochemistry of epidermal mucous cells during the Alevin and Fry stages of the brown trout SalmoTrutta. J. Zool. 197, 463-471.

Bradshow, C. M., A. S. Richard, and M. M. Sigel, 1971: IgM antibodies in fish mucus. Soc. exptl. Biol. Med. Proc. 136, 1122-1124.

Burkhardt-Holm, P., 1997: Lectin histochemistry of rainbow trout (Oncorhynchus mykiss) gill and skin. Histochem. J. 29, 893-899.

Cameron, A. M., and R. Endean, 1973: Epidermal secretions and the evolution of venom glands in fishes. Toxicon. 11, 401-410.

Fletcher, T. C., and P. T. Grant, 1968: Glycoproteins in the external mucous secretions of the place, Pleuronectes platessa and some other fishes. Biochem. J. 106, 110-118.

Harris, J., and P. Hunt, 1973: Epithelial mucus of the Atlantic salmon (Salmo solar L.). Trans. Biochem. Soc. 1, 153-155.

Kumari, U., M. Yashpal, S. Mittal, and A. K. Mittal, 2009: Histochemical analysis of glycoprotein's in the secretory cells in the gill epithelium of a catfish, Rita rita (Siluriformes, Bagridae). Tissue Cell [Epub ahead of print]. 
Mittal, A. K., and M. Whitear, 1979: Keratinization of fish skin with special reference to the catfish Bagarius bagarius. Cell Tissue Res. 202, 213-230.

Mittal, A. K., T. Ueda, O. Fujimori, and K. Yamada, 1994: Histochemical analysis of glycoproteins in the unicellular glands in the epidermis of an Indian freshwater fish Mastacembelus pancalus (Hamilton). Histochem. J. 26, 666-677.

Nakamura, O. T., T. Watanabe, H. Kamiya, and K. Muramoto, 2001: Galectin containing cells in the skin and mucosal tissues in Japanese conger eel, Conger myriaster: an immunohistochemical study. Dev. Comp. Immunol. 25, 431-437.

Pearse, A. G. E., 1985: Histochemistry - Theoretical and Applied, 4th edn. Edinburgh: Churchill Livingstone.

Pigman, W., 1977. Mucus glycoprotein. In: The Glycoconjugates (M. I. Horowitz and W. Pigman, eds). Vol. 1. New York: Academic Press, pp. 131-137.

Pinky, S., S. Mittal, and A. K. Mittal, 2008: Glycoproteins in the epithelium of lips and associated structures of a hill stream fish Garra lamta (Cyprinidae, Cypriniformes): a histochemical investigation. Anat. Histol. Embryol. 37, 101113.

Schick, B., F. Habermann, and F. Sinowatz, 2009: Histochemical detection of glycoconjugates in the canine epididymis. Anat. Histol. Embryol. 38, 122-127.

Shephard, K. L., 1994: Functions for fish mucus, Rev. Fish Biol. Fish. 4, 401-429.

Whitear, M., 1981: Secretion in the epidermis of polypteriform fish. Z. Mirkosk. Anat. Forsch. 95, 531-543.

Whitear, M., and A. K. Mittal, 1983: Fine structure of the club cells in the skin of ostariophysan fish. Z. Mirkosk. Anat. Forsch. 97, 141-157.

Zaccone, G., S. Fasulo, P. Lo Cascio, and A. Licata, 1985: Binding of concanavalin A to secretory epidermis in the fish Blennius sanguinolentus pallas: light microscopic and ultrastructural studies. Basic Appl. Histochem. 29, 135147. 